\title{
Cognitive technologies in cluster of identification of irrational images of Romanticism and symbolism
}

\author{
Vladislav Zhukov ${ }^{1, *}$ and Anastasia Smirnova ${ }^{1}$ \\ ${ }^{1}$ Saint Petersburg State University of Industrial Technologies and Design. Saint Petersburg, Russia
}

\begin{abstract}
The main goal of the project is to use cognitive technologies to create an author's, metaphorical, temporal system model of images of modern jewelry using the linguo-combinatorial method in the implementation of retro styles - locally stable structures of the design landscape represented by the cultural code of the irrational eidos of poetry and prose of North American symbolism and romanticism of the mid-19th century..
\end{abstract}

\section{Introduction}

The theory of design is the laws of designing, forecasting, and improving the appearance of a person through the upgrade of jewelry in the implementation of the principle of the modern strategy of jewelry art, which defined design as a link between the world of fashion and the jewelry industry. This is confirmed by the statement of the master of world design, the president of the project "VICENZAJRO" Roberto Dietri: "A work of art can only be displayed in an environment of works of art" [1].

Images of a visual-symbolic cognitive information dynamic system with a locally stable structure, represented in jewelry art, are connected on the one hand with the narrative level [2] of events in people's lives, determined by their worldview, culture, behavior, and attitude to each other, and on the other hand, the synergetic properties of images allow them to correlate with the fundamental laws of nature on the principles of NBICS-convergence, creating a harmonious cultural landscape of design [3, 4].

The field of study is the lyrics and prose of North American symbolism and romanticism of the mid-19th century, which is based on the work of Edgar Allan Poe.

\section{Materials and methods}

To create images of design objects - a ring, a pendant, earrings and a pair of brooches, represented by visual-symbolic cognitive information dynamic systems (VCIDS) with locally stable structures (LUS) in the development of cognitive technologies of plastic arts and design, methods of linguistic-combinatorial and tabular modeling were used..

\footnotetext{
* Corresponding author: 1t_zhukova@mail.ru
} 


\section{Results}

Edgar Allan Poe, along with Burne-Jones, the creator of special female imagery, largely anticipated the very spirit of symbolism. He not only updated the possibilities of fantastic storytelling, but also its aesthetic theory.

Symbolism borrowed from E. A. Poe's analytical approach to creativity and the striking accuracy of poetic fiction, which awakens feelings of mysterious passion for the otherworldly mystical life.

Emphasizing the genius of this "wonderful inventor", whose work gave rise to both a fantastic novel and a modern detective story, as well as an idea that reconciled the semblance of mathematics and mysticism, the symbolists made the goal of creating "pure poetry".

Between 1880 and 1900, poets and artists found in the stories of E. A. Poe the origins of their imagination, mystical feelings, and worldview. Thus, O. Redon, as a sign of deep recognition of the writer's work, dedicated a series of lithographs to him in 1882 [5].

Symbolism has become a cognitive doctrine of creativity, the vector of which directs art into the information field, with signs that the canon of European idealism is undergoing fundamental changes for various reasons. It is transformed from "Platonism" into the field of Kant's ideas. At the same time, the dynamics of changes in the symbol-sign system shows its evolution towards greater expression, that is, it does not tell and describe, but expresses and sounds eidically. The very fabric of creativity that brings it to its center is refined, and the very desire for it is revealed in the ontological reality represented by "pure" sound, color, and tone. Sometimes the search for a priori forms of creativity breaks with the "realm of phenomena" and seeks its result in the emphatically irrational beginning of the universal rhythm [6] in the spontaneous cognitive dimension of the narrative.

In this case, symbols are the elusive matter of creativity itself, which is the "art of thinking in images", represented by the information field, which in design theory can be considered a representation of the second nature [7], prosody of its own semiotic language of metaphorical models that perform the metaphysical function of symbolism, subject to the laws of supernatural synergetic self-organization.

This is the natural complexity and logic of symbolism, which seeks the superhuman in the obviously human, linking together all the layers of ontological and semiotic reality, connecting them with each other [8].

The similarity between the ontological and semiotic realities is based on the existence of a "common rhythm" in them. By rhythm, we should not mean "a certain order in time", but a certain harmony, which is possessed by a sign or symbol [9], which forms the eidos and the concept of the image of the design object designated by them.

This "common rhythm" shows that only those things that have a common essence or meaning, the same "life aspect", can be transformed and pass into each other. Then rhythm can be understood as a set of quantitative and/or qualitative values, but also as a formal pattern defined by rhythmic representations, i.e., the similarity of form and location in space $[10,11]$.

Studies of this problem show that symbols in pragmatic and cognitive relations have certain rhythms that provide a symbolic dimension of the narrative [2] of cognitive technologies in design theory.

It turns out that the rhythms and dynamics of behavior allow us to establish relationships between different planes of reality, demonstrating a deep and constant relationship between rhythm and emotion. In addition, the place of symbolism is located within the archetypal plane due to the principle of concentration, when similar substances can be represented as a single whole. In addition, having the properties of uniqueness, the leading rhythm transforms everything that can manifest itself as a separate one, which is 
clearly seen in the example of the images of symbolic poetry by E. A. Poe, the poem "The Raven" [12]. Here, not only do all the crows ascend to the common raven, but any symbolic project that resembles a raven is also a raven. This shows the consequences of the manifestation of the principle of " sufficient identity» (tab.1).

Table 1. Visual cognitive Information Dynamic System (VKIDS), represented by the Raven image

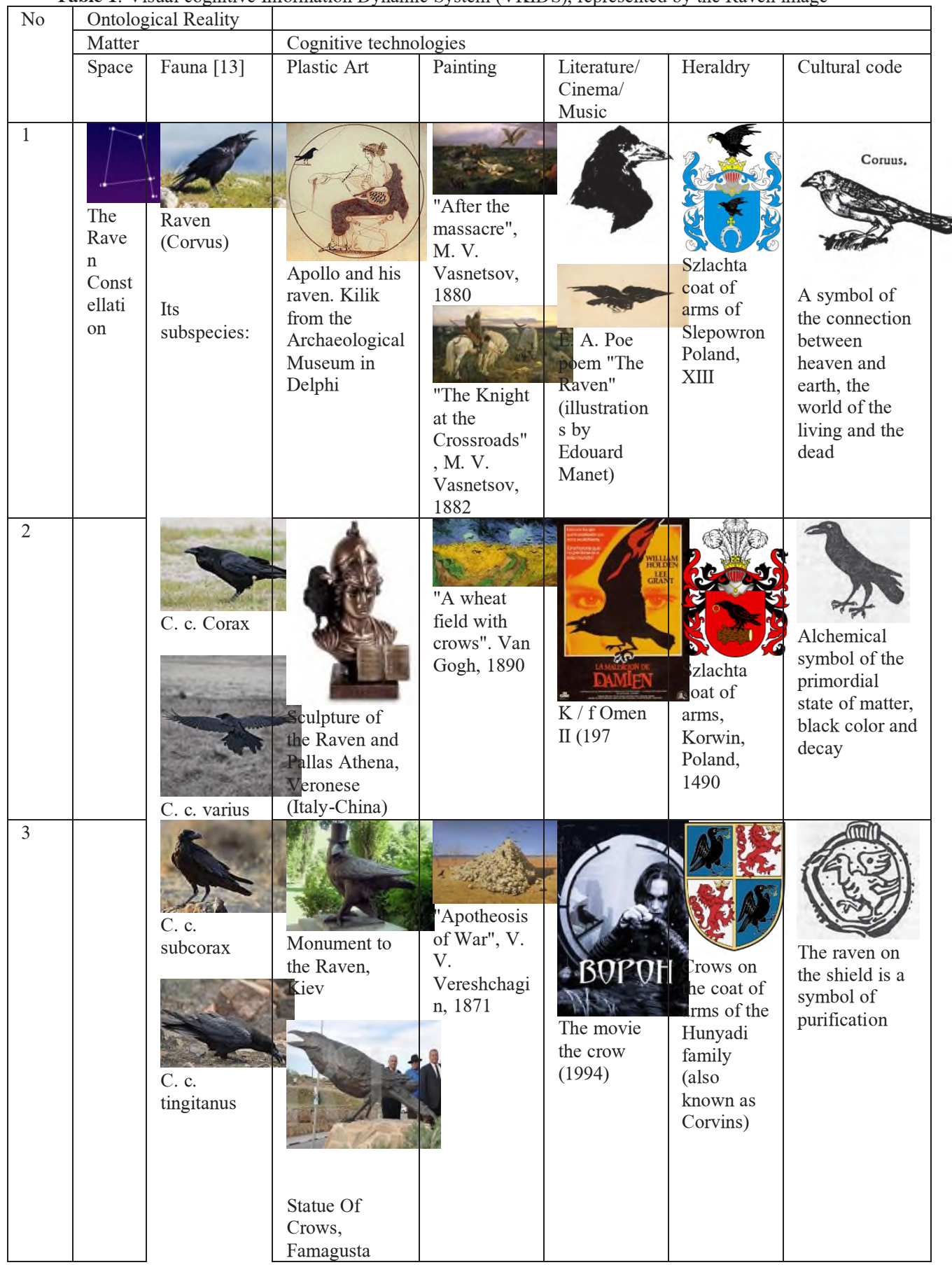




\begin{tabular}{|c|c|c|c|c|c|c|}
\hline 4 & $\begin{array}{l}\text { Tibetanus } \\
\text { C.c. } \\
\text { C. c. } \\
\text { us }\end{array}$ & $\begin{array}{l}\text { Piraeus } \\
\text { Athena, 340- } \\
330 \mathrm{BC}\end{array}$ & $\begin{array}{l}\text { "The } \\
\text { Raven", } \\
\text { Odilon } \\
\text { Redon, } \\
\text { 1882 }\end{array}$ & $\begin{array}{l}\text { Misney } \\
\text { Productions } \\
\text { "Sleeping } \\
\text { Beauty", } \\
\text { 1959 (raven } \\
\text { Diabolos } \\
\text { was an } \\
\text { assistant to } \\
\text { the evil } \\
\text { sorceress } \\
\text { Maleficent) }\end{array}$ & $\begin{array}{l}\text { (Russia) } \\
\text { rekludova }\end{array}$ & $\begin{array}{l}\text { Heraldic } \\
\text { symbol of } \\
\text { foresight and } \\
\text { longevity } \\
\text { (depicted in } \\
\text { black) }\end{array}$ \\
\hline 5 & $\begin{array}{l}\text { C. c. } \\
\text { principalis }\end{array}$ & $\begin{array}{l}1 \\
\text { Митра в } \\
\text { солнечной } \\
\text { короне с } \\
\text { Вороном - } \\
\text { вестником } \\
\text { Солнца. } \\
\text { Античный } \\
\text { барельеф }\end{array}$ & $\begin{array}{l}\text { Susting } \\
\text { "Sinister", } \\
\text { N. K. } \\
\text { Roerich, } \\
1901\end{array}$ & $\begin{array}{l}\text { Folk } \\
\text { Cossack } \\
\text { song " } \\
\text { Black } \\
\text { Raven» } \\
\text { English folk } \\
\text { song "Three } \\
\text { ravens" } \\
\text { (TRANS. } \\
\text { "the } \\
\text { Scottish } \\
\text { song" by A. } \\
\text { S. Pushkin) }\end{array}$ & $\begin{array}{l}\text { Rod } \\
\text { Butorina } \\
\text { (Russia) }\end{array}$ & $\begin{array}{l}\text { Thristianity: a } \\
\text { symbol of } \\
\text { seath, the } \\
\text { devil, the } \\
\text { Plague, evil } \\
\text { spirits }\end{array}$ \\
\hline 6 & $\begin{array}{l}\text { laurencei } \\
\text { C.c. } \\
\text { C. c. } \\
\text { hispanus }\end{array}$ & $\begin{array}{l}\text { Скульптура } \\
\text { «Ворон» } \\
\text { "The Raven" } \\
\text { the creative } \\
\text { group "the } \\
\text { Forge» }\end{array}$ & $\begin{array}{l}\text { Kaven } \\
\text { Kuth and } \\
\text { salmon", E. } \\
\text { M. Rachev, } \\
1961 \\
\\
\text { The Woman } \\
\text { with the } \\
\text { Raven, by } \\
\text { Pablo } \\
\text { Picasso, } \\
\text { 1904 }\end{array}$ & 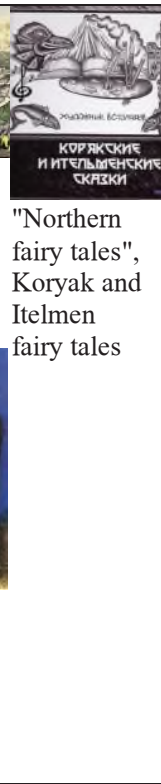 & $\begin{array}{l}\text { Grayvoron } \\
\text { (Belgorod } \\
\text { region, } \\
\text { Russia), } \\
1995\end{array}$ & $\begin{array}{l}\text { European } \\
\text { folklore: } \\
\text { wisdom, } \\
\text { justice }\end{array}$ \\
\hline
\end{tabular}




\begin{tabular}{|c|c|c|c|c|c|c|}
\hline 7 & $\begin{array}{l}\text { White- } \\
\text { cheeked } \\
\text { raven } \\
\text { (Albicollis) }\end{array}$ & $\begin{array}{l}\text { Bedside lamp, } \\
\text { USA }\end{array}$ & $\begin{array}{l}\text { "A boy } \\
\text { trains a } \\
\text { crow", } \\
\text { author } \\
\text { unknown, } \\
1879\end{array}$ & $\begin{array}{l}\text { Anna } \\
\text { Anderson } \\
(1874-1930) \\
\text { - Gerda and } \\
\text { the Crows } \\
\text { to H. H. } \\
\text { Andersen's } \\
\text { fairy tale " } \\
\text { The Snow } \\
\text { Queen» }\end{array}$ & $\begin{array}{l}\text { Saint-Paul- } \\
\text { les-Dax } \\
\text { (France }\end{array}$ & $\begin{array}{l}\text { Norse } \\
\text { Mythology: } \\
\text { Hugen } \\
\text { (Thought) and } \\
\text { Munen } \\
\text { (Memory) }\end{array}$ \\
\hline 8 & $\begin{array}{l}\text { Piebald } \\
\text { raven } \\
\text { (Corvus } \\
\text { albus) }\end{array}$ & $\begin{array}{l}\text { Lamp "The } \\
\text { Raven", Seletti }\end{array}$ & $\begin{array}{l}\text { Rarlstein's } \\
\text { Raven", } \\
\text { Mikolas } \\
\text { Ales, } \\
\text { National } \\
\text { Gallery in } \\
\text { Prague, } \\
\text { 1882 }\end{array}$ & $\begin{array}{l}\text { Date } \\
\text { "Barnaby } \\
\text { Rudge", by } \\
\text { Charles } \\
\text { Dickens }\end{array}$ & $\begin{array}{l}\text { Oberbergki } \\
\text { rchen } \\
\text { (municipal } \\
\text { ity of } \\
\text { Germany, } \\
\text { Bavaria) }\end{array}$ & $\begin{array}{l}\text { Japan, China: a } \\
\text { pair of ravens- } \\
\text { a symbol of } \\
\text { strong love }\end{array}$ \\
\hline 9 & $\begin{array}{l}\text { Desert } \\
\text { Brown- } \\
\text { headed } \\
\text { Raven } \\
\text { (Corvus } \\
\text { ruficollis) }\end{array}$ & $\begin{array}{l}\text { Miniature } \\
\text { jewelry } \\
\text { sculpture, Ann } \\
\text { Marie } \\
\text { Cianciolo }\end{array}$ & $\begin{array}{l}\text { The } \\
\text { Monastic } \\
\text { Raven, by } \\
\text { Henry } \\
\text { Stacey } \\
\text { Marks, } \\
\text { Bristol City } \\
\text { Museum } \\
\text { and Art } \\
\text { Gallery, } \\
1870\end{array}$ & $\begin{array}{l}\text { Jvan } \\
\text { Bunin's } \\
\text { short story } \\
\text { 'The } \\
\text { Raven", a } \\
\text { series of } \\
\text { hort stories } \\
\text { 'Dark } \\
\text { Alleys", } \\
1945 \\
\text { The poem } \\
\text { "Metamorp } \\
\text { hoses", by } \\
\text { Publius } \\
\text { Ovid Nason }\end{array}$ & $\begin{array}{l}\text { Ravenstein } \\
\text { in the } \\
\text { community } \\
\text { of Oss } \\
\text { (Netherlan } \\
\text { ds) }\end{array}$ & $\begin{array}{l}\text { Greek } \\
\text { Mythology: the } \\
\text { raven } \\
\text { accompanies } \\
\text { the gods: } \\
\text { Kronos } \\
\text { (Saturn), } \\
\text { Apollo, Helios, } \\
\text { Athena } \\
\text { (helmet) - a } \\
\text { symbol of } \\
\text { good luck, the } \\
\text { giver of light, } \\
\text { God's } \\
\text { messenger }\end{array}$ \\
\hline 10 & $\begin{array}{l}\text { American } \\
\text { Raven } \\
\text { (Corvus } \\
\text { brachyrhync } \\
\text { hos) }\end{array}$ & $\begin{array}{l}\text { Miniature } \\
\text { jewelry } \\
\text { sculpture, Ann } \\
\text { Marie } \\
\text { Cianciolo }\end{array}$ & $\begin{array}{l}\text { Dobycha } \\
\text { Mavens", } \\
\text { Marceli } \\
\text { Harasimowi } \\
\text { cz, Lviv art } \\
\text { gallery, } \\
1888\end{array}$ & $\begin{array}{l}\text { BOpOHiF } \\
\text { "The } \\
\text { Crow", } \\
\text { George } \\
\text { Dawes } \\
\text { Green, 2009 }\end{array}$ & $\begin{array}{l}\text { Coat of } \\
\text { arms of } \\
\text { Ehrenhaus } \\
\text { en } \\
\text { (Austria) }\end{array}$ & $\begin{array}{l}\text { The raven is a } \\
\text { symbol of the } \\
\text { sun. The } \\
\text { characteristic } \\
\text { solar emblem } \\
\text { in China is a } \\
\text { red disk with a } \\
\text { three-legged } \\
\text { raven, }\end{array}$ \\
\hline
\end{tabular}




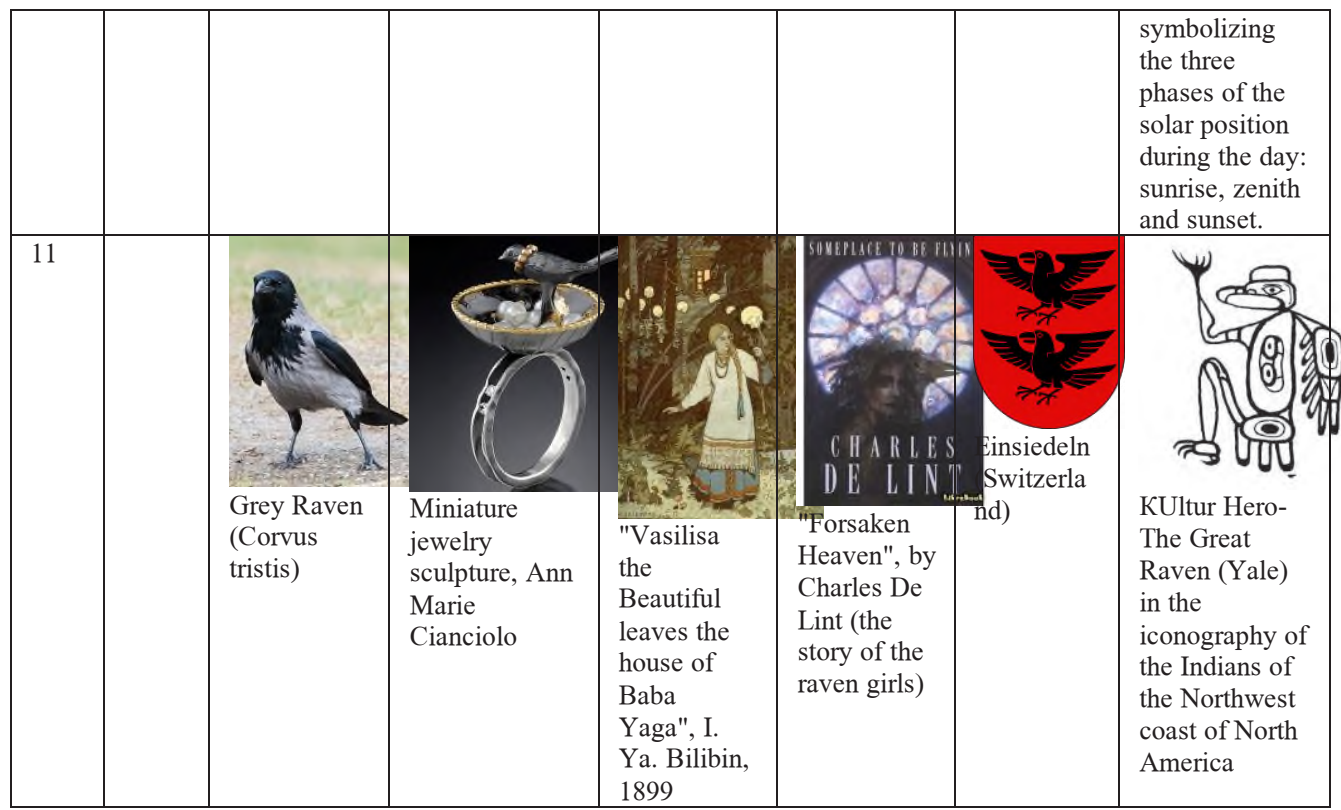

In cognitive technologies, symbols exist only in the imagination of consciousness, from where they are projected onto nature, taking its language, essence and form, or transforming its essence and form into dramatic plots of characters with esoteric properties that base symbolism in the space of the macro-microcosm.

It turns out that the designated symbolic and symbolic language of images and emotions is a reflection of both external phenomena and events (cosmic order), and those internal mental processes of a person concerning thought, the moral order of things, mental development, evolution, knowledge, beliefs, principles, and so on.

The symbols of their entities, properties, and relations in KIDS arising jewelry, integrates into the landscape of society, culture, Universe, design, and as metaphorical models that contain philosophical-semantic information, with symbolic functions, converging with the optimal adaptive phenomenon of high $[14,15]$.

The results of the research presented in Table 1 served as information for the creation of the "Raven" parure, consisting of earrings, pendants, rings, and brooches Fig. 1.
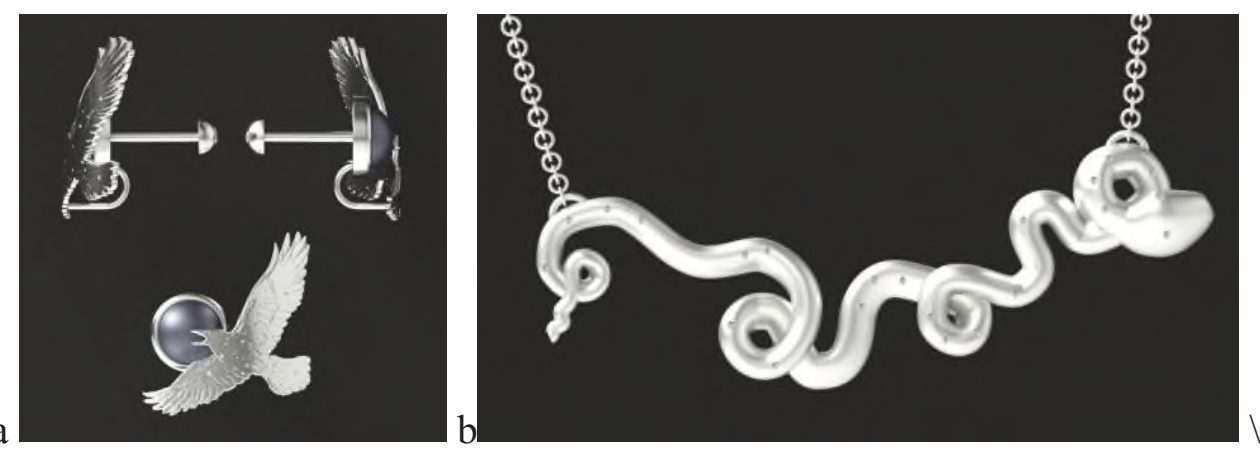

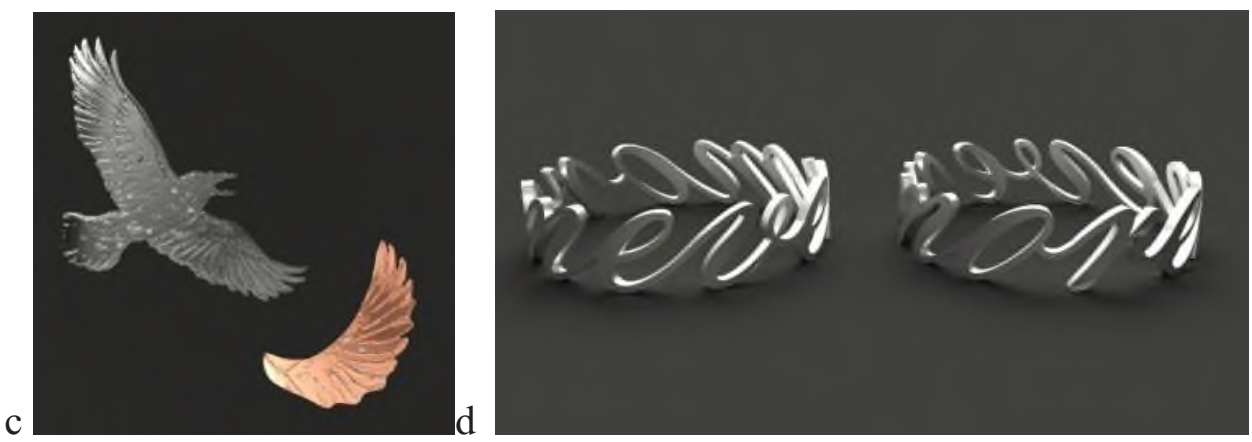

Fig. 1 Parure "Raven": a) Earrings "Raven"; b) Pendant "Hydra"; c) A pair of brooches "Raven"; d) Ring " Nevermore».

\section{Discussion}

The images of the pyuria "Raven" created by the linguo-combinatorial method showed what makes symbolism. The work of E. A. Poe, as the top in the ascending chain of the successive development of North American lyrics, which gave the most vivid, "accomplished" poems to world literature, became the optimal material for the realization of the artistic aspirations of symbolism in jewelry art.।

\section{Conclusions}

In this work, the goal is the achieved-the study of the still unnoticed or underestimated features of the symbolist phenomenon.

The study was performed with the financial support of RFBR, research project No. 20-312-90056 (the reported study was funded by RFBR, project № 20-312-90056).

\section{Reference}

1. M. Bronwen, Ringham Felicitas Dictionary of Semiotics. (Moscow, LIBROCOM", 2010)

2.M. V. Kovalchu Convergence of science and technology-a breakthrough in the future ((Moscow, Knowledge, 2010)

3. J. Cassou, P. Brunel, F. Claudon, etc. Encyclopedia of Symbolism: Painting, Drawing, and Sculpture. Literature. Music (Moscow, Republic, 1999)

4.R. Steiner The philosophy of freedom. The main features of a modern worldview. Yerevan: Noi, 1993.

5. Solomonik A. B. Semiotics and theory of knowledge (Moscow, LIBROCOM, 2018)

6. R. Guenon Essays on Tradition and Metaphysics (Moscow, Azbuka, 2010)

7.X. Kirlo Dictionary of symbols. 1000 articles on the most important concepts of religion, literature, architecture, history (Moscow, Tsentrpoligraf, 2007) 
8. G. Davi, V. A. Volkov, E. V. Vonsky, G. I.Kuznetsova Outstanding chemists of the world (Moscow, Vysshaya shkola, 1991)

9. A.Boethius, A. Boethius Enciklopediya (Moscow,: Mysl, 2010).

10. E. A. Poe Poeticheskiy princip (Moscow, TERRA, 2009).

11. M. B. Ignatiev Cybernetic picture of the world. Complex cyber-physical systems (St. Petersburg: GUAP, 2014)

12. V. L. Zhukov A.M. Smirnova JPG, 2 (2017). 